\title{
The Study of Financial System in Imam Khomeini Relief Committee (Rural and Urban) in Kohgiluyeh and Boyer-Ahmad
}

\author{
Seyed Yaqoub Zeraat Kish $^{1}$ \& Seyed Mosa Jafari Nejad ${ }^{1}$ \\ ${ }^{1}$ Department of Economic and Management, Yasouj branch, Islamic Azad university, Yasouj, Iran \\ Correspondence: Seyed Yaqoub Zeraat Kish, Department of Economic and Management, Yasouj branch, Islamic \\ Azad university, Yasouj, Iran \\ Received: January 25, 2016 \\ Accepted: April 10, 2016 \\ Online Published: April 18, 2016 \\ doi:10.5430/jbar.v5n1p54 \\ URL: http://dx.doi.org/10.5430/jbar.v5n1p54
}

\begin{abstract}
In this practical article, the financial control status of Relief Committee in Kohgiluyeh and Boyer-Ahmad is examined. In this study, data was collected by the questionnaire and data analysis was performed by SPSS software and binomial distribution. The population of the study is the area of Tax Administration of Relief Committee Agency in kohgiloyeh and Boyer-Ahmad and since the size of the population is limited, therefore, the views of all people are applied. Finally, according to the results of the control performance and measures that directly affect the reliability of accounting records and financial statements, and in order to achieve different objectives and it is recommended that monitoring of the entire level of management control should involve all levels of the organization and various activities.
\end{abstract}

Keywords: Internal control, Financial control, Relief Committee

\section{Introduction}

The purpose of internal control and audit system is to improve the administrative and financial management through its threat of financial behaviors that lead to waste and misallocation of resources and corruption. Establishment and continuation of a strong internal control system in the organization provide effective management to manage the organization (Antle, 1982). The most important issue that makes the control essential is that predictions and operational programs in organizations have always been associated with error and to fix the errors and correcting the operation, control is the only solution (Foster and Gupta, 1994). The dynamic environment of the organization is another reason for the necesity of control. Organizations for their survival must become aware of environmental changes and coordinate with them, and control is the means of this awareness (Simon and Guilding, 2008). Ensuring the quality of goods and services in large organizations in large and complex applications are available only through an effective system of practical control and all are the evidence of the need for control in modern organizations (Amershi, and Butter, 1988).

According to the importance of internal controls, particularly in the public sector because of the involvement of public property, proper attention to this issue could be fertile ground for accountability and responsiveness of various government departments for their available resources. According to the concepts of internal control in the public sector because it is more visible, the lawmakers of financial rules such as law court should more focus on the in thenal control (Amershi,. and. Stoeckenius, 1983).

Weak internal controls not only increase the potential for abuse and fraud in the organization, but also affect the work of auditors, and if the weaknesses in the system are ignored, the system will be unable to provide reliable and accurate report (Anthony, 1998). Therefore, the internal control system should inform the weaknesses to the management by the auditors to create the environment that the mangers od their tasks to meet the needs of the users of the financial statements, and the auditors can provide the reports in accordance with auditing standards (Dixon and Smith, 1993).

\section{Research Methodology}

In the inferential statistics, since this study is a correlation study and because the main purpose of the survey may be creating the relationship or lack of relationship, and the use of relationships in the prediction, the inferential analysis of the gathered data from the questionnaires using SPSS software and test research hypotheses by means of the "binomial" test, the status of each of the main variables is studied (Coad, 1996). 


\section{Results}

Basic or primary control is one of the internal control of accounting (financial) that it is called the minimum internal controls to ensure accurate and complete record of the activities of the trade agency, such as: observing fixed assets, overview turnover to determine unusual items, preparation of bank reconciliation or conflict resolution, prepared trial balance (Shannon, 2006).

The controls that are established to ensure the suitable implementation of the internal controls are known as supervisory controls that are another types of internal controls of accounting (financial). Activities such as monitoring the accuracy of documents and registers financial activities, effective and regular pursue, the objective correspondence, the fixed organizational properties, preparing the bank reconciliations by the independent person of the bank account holder, etc are the control activities led by organizations (Baiman, 1982).

Protective control is another activity to the proper use of assets and their protection is used to prevent damage or misuse of assets, and the subset of internal controls are considered for accounting (financial).

Regarding that the cash and non-cash assets (property) have a key role in achieving the pre-determined goals, therefore, they must be properly maintained to prevent any misappropriation, misuse and misappropriation. Financial information related to capital assets (property) should be disclosed due to the fact that a large part of the resources should be spent on building and buying them (Blocher and Lin, 1999). Other control factor is considered essential for effective internal control system that in which ther are control activities for each business level. Separation of duties controls, including accounting internal control activities (financial) are that the separation of duties and responsibilities among staff so that no one is responsibility for performing and recording a transaction from beginning to end so that the one's activity is not considered as the other's activity. Separation of duties is considered as a preventive control. Analyzes shows that the effectiveness of the separation of duties depends on the detective controls in the system (eg the internal or depended auditors) and the possibility that these controls detect fraud.

This research has been followed by examining the activities and the internal control structure, including all measures in the Imam Khomeini Relief Committee of Kohgiluyeh and Boyer Ahmad, challenges, shortcomings and weaknesses in the internal control system of funding would be possible to identify and to introduce planners to the planning and implementation of the right policies, the achievement of entity objectives in the area of reliability of financial reporting, effectiveness and efficiency of operations and compliance with laws and regulations relating to the organization provide reasonable assurance.

Control performance and measures that directly affect the reliability of accounting records and financial statements and this organization is disorganized to achieve goals such as protection of assets, reliability of accounting records due to undesirable preparation of reliable financial statements, and the weak status of internal control system.

According to the results of the present study, it is recommended that allocation of duties and responsibilities should be carried out in such a way that the reasonable assurance should be achieved regarding the absence of any breach in the obtained reports, and complete level of management control should involve all levels of the organization and various activities. Also, it is recommended that there should be an audit committee to create the suitable relationship between the board of directors, the independent auditors, and internal auditors of the orginaziation.

\section{References}

Amershi, A. H. \& Worth Butter, J.E. (1988). Explorations in the Theory of Single And Multiple Agent Agencies, Amershi.

Amershi, A. \& H. Stoeckenius. (1983). The Theory of Syndicates and Linear Sharing Rules. Econometrica. Sept. 160-1407. http://dx.doi.org/10.2307/1912281

Anthony, R.N. (1998). Management Control Systems. Irwin, McGraw-Hill.

Antle, R. (1982). The Auditor As An Economic Agent. Journal of Accounting Research. Autumn, 27-503. http://dx.doi.org/10.2307/2490884

Anderson Shannon W. (2006). "Managing Costs and Cost Structure throughout the Value Chain:Research on Strategic Cost Management" , Handbook of Management Accounting Research, 2. Oxford: Elsevier. http://dx.doi.org/10.1016/S1751-3243(06)02001-3

Baiman, S. (1982). Agency Research In Managerial Accounting: A Survey. Journal of Accounting Literature, 1, 154-213.

Blocher E. , K. Chen \& T. Lin. (1999). Cost management: A Strategic Emphasis. The McGraw-Hill Companies, Inc. 
Cadez Simon \& Chris Guilding. (2008). An exploratory investigation of an integrated contingency model of strategic management accounting. Accounting, Organizations and Society, 33, 836-863. http://dx.doi.org/10.1016/j.aos.2008.01.003

Cinquini Lino \& Andrea Tenucci. (2007). Is the adoption of Strategic Management Accounting techniques really "strategy-driven"? Evidence from a survey". http://MPRA.ub.uni-muenchen.de/11819

Coad, A. (1996). Smart work and hard work: explicating a learning orientation in strategic management accounting. Management Accounting Research, 7(4), 387-408. http://dx.doi.org/10.1006/mare.1996.0022

Dixon R. \& D. Smith. (1993). Strategic management accounting. Omega, 21(6), 605-18. http://dx.doi.org/10.1016/0305-0483(93)90003-4

El-Dyasty Mohamed M. (2007). A Framework to Accomplish Strategic Cost Management. http://ssrn.com/abstract=704201

Foster G. \& M. Gupta (1994). Marketing, cost management and management accounting. Journal of Management Accounting Research, 6, 43-77. 